\title{
Transcendence Matters: Do the Ways Family Members Experience God Meaningfully Relate to Family Life?
}

\author{
Hilary Dalton \\ Kansas State University \\ David C. Dollahite \\ Brigham Young University, david_dollahite@byu.edu \\ Loren D. Marks \\ Brigham Young University - Provo, loren_marks@byu.edu
}

Follow this and additional works at: https://scholarsarchive.byu.edu/facpub

Part of the Other Social and Behavioral Sciences Commons

\section{Original Publication Citation}

*Dalton, H., Dollahite, D., \& Marks, L. D. (2018). Transcendent matters: Do the ways family members experience God meaningfully relate to family life? Review of Religious Research, 60, 23-47.

\section{BYU ScholarsArchive Citation}

Dalton, Hilary; Dollahite, David C.; and Marks, Loren D., "Transcendence Matters: Do the Ways Family Members Experience God Meaningfully Relate to Family Life?" (2017). Faculty Publications. 4852. https://scholarsarchive.byu.edu/facpub/4852 accepted for inclusion in Faculty Publications by an authorized administrator of BYU ScholarsArchive. For more information, please contact ellen_amatangelo@byu.edu. 


\title{
Transcendence Matters: Do the Ways Family Members Experience God Meaningfully Relate to Family Life?
}

\author{
Hilary Dalton $^{1}$ (D) David C. Dollahite ${ }^{2} \cdot$ Loren D. Marks $^{2}$
}

Received: 29 December 2016/ Accepted: 18 October 2017/Published online: 1 November 2017

(C) Religious Research Association, Inc. 2017

\begin{abstract}
As more Americans continue to move away from an institutional approach to religion and spirituality to a more personal approach, it is important to explore the ways that personal perspectives about God influence various aspects of life including family life. This study explored how participants viewed and experienced God as an authority figure (Directive Transcendence), as a close confidant (Intimate Transcendence), or as both (Authoritative Transcendence). In-depth interviews with 198 religious families from across America were analyzed using a team-based qualitative approach. These analyses revealed that participants experienced God as both an authority figure and as a close confidant. Both types of experiences are associated with family relationships in different ways. Concepts relating to ideas of authority, parenting styles, and attachment theory are used to help understand familial impacts from how one experiences God.
\end{abstract}

Keywords God · Family · Religion · Attachment · Authority

Hilary Dalton

dhilary5@gmail.com

David C. Dollahite

david_dollahite@byu.edu

Loren D. Marks

loren_marks@byu.edu

1 Applied Family Science Program at KSU, Kansas State University, 119 Justin Hall, Lovers

Lane, Manhattan, KS 66502, USA

2 School of Family Life, Brigham Young University, 2092C JFSB, Provo, UT 84602, USA 


\section{Introduction}

Recent surveys conducted by Pew Research Center and others indicate that while most Americans continue to believe in God, many are continuing to move away from an institutional approach to a more personal approach in matters of religion and spirituality. ${ }^{1}$ It therefore may be increasingly important to explore the ways that personal experiences of God are related to various aspects of life-including family life. An important but understudied aspect of spirituality is how individual perceptions and experiences of God relate to family relationships. Most research addresses religious behaviors such as attendance, prayer, or salience (how important religion is) or literalness of belief (e.g., biblical inerrancy). Relatively little research has addressed connections between how family members experience God and their family relationships.

Beliefs about and experiences of God are not maintained in a vacuum, but can affect other parts of life and other relationships (Emery et al. 1984; Gallagher et al. 2015). Religious beliefs and practices can either help or harm family relationships and several scholars have argued for awareness of both potentialities (Burr et al. 2012; Mahoney 2010; Pargament and Mahoney 2005). We have recently proposed that a system of religious dualities influences family life in various ways (Dollahite, Marks, \& Dalton, in press). One of those dualities is whether family members experience God mainly as an authority figure, mainly as a close confidant, or as both. In this article, we explore whether and how family members' experiences of God may be associated with family relationships. Within the concept "experiences of God" we include: (a) perceptions (what God is like; how God relates and responds to us), (b) expectations (what will God do and not do; what God expects of us), and (c) direct experiences (how God has guided or responded to us).

\section{Review of the Literature}

Mahoney (2013) has called for more research on the influence of substantive, specific beliefs as a way to further our understanding of the religion-relationships linkage. Specifically, she proposed the concept of relational spirituality to capture the overlap of relationships and spirituality, and to connect religiosity with marriage and family relationships. She identified three tiers of spiritual beliefs that can impact family relationships in both helpful and harmful ways: God, family members, and religious communities (Mahoney 2013). This study will explore how family members' experiences of God are related to family life. Froese and Bader (2010) demonstrated that differences in views of God influence attitudes about a wide range of issues. Konieczny (2013) found meaningful differences in the way Catholics approach work and family life based on whether they attended a more traditional or more progressive parish.

In this article, we employ theoretical constructs that deal with attachment and authority to explore how a person's experience of God influences her/his family life.

\footnotetext{
${ }^{1}$ http://www.pewresearch.org/fact-tank/2016/08/24/why-americas-nones-left-religion-behind/.
} 
We connect attachment theory (Granqvist and Kirkpatrick 2013) and what we call authority theory to how people say they experience God. Attachment theory addresses what the religious studies literature refers to as more person-centered "horizontal relationships" with the divine, while our proposed construct of authority theory will be applied to a more hierarchal "vertical relationship" (Goodenough 2001; Shichida et al. 2015).

\section{Attachment Theory and Experiences of God}

Just as one's family relationships or attachments can influence one's experiences of God (Granqvist and Kirkpatrick 2013), one's experiences of God can impact family relationships (Marks and Dollahite 2017). In Selvam's (2014) review of psychology literature on youth relationships with God, he argued that although studies about parenting styles and attachment to God are not consistent, these studies consistently point to important connections between relationships within families and one's religious beliefs and attachment to God.

Several theoretical (Exline 2002; Granqvist and Kirkpatrick 2013; Knabb and Emerson 2013) and empirical (Ellison and Lee 2010; Gall et al. 2007; Granqvist 1998; Miner et al. 2014) articles have discussed how attachment theory relates to religion, especially the phenomenon of seeing God as an attachment figure (Granqvist et al. 2010). In this literature, God is typically viewed as a secure base from which a person can obtain the courage and confidence to explore religious beliefs and the secular world, and as a safe haven where a person can turn when in need of love and comfort (Granqvist and Kirkpatrick 2013; Knabb and Emerson 2013). Although attachment theory has been linked to experiences of God, discussion about the authority of an attachment figure is limited. We seek to expand the literature by exploring the overlaps between experiences of God as someone to turn to for love and comfort, and experiences of God as a firm authority figure.

\section{Authority Theory and Experiences of God}

We suggest the potential value of what we call "authority theory" in exploring how experiences of God as an authority figure might be associated with family relationships. Omer et al. (2013) supplemented attachment theory by discussing parental authority through what they called the anchoring function. According to Omer et al., for a parent to be able to safeguard her/his parental role and "keep [children] from venturing into dangerous waters" (p. 195), the parent needed to be anchored in her/his parental role through structure, presence, social support, and self-control. They theorized that as parents are anchored in their parental role, they are better able to fulfill the role of being a safe attachment figure for their children. Although Omer et al. (2013) did not specifically relate the anchoring function to God or to one's attachment to God, these concepts may have interesting ties. God, like an anchored parent, can be experienced as structured, present, providing social support, and showing self-control as an anchored and authoritative attachment figure-or as an absent or cold ruler. 
Billions of people across the earth (and throughout history) believe in, turn to, rely on, obey, commit to, sacrifice for, worship, and in other ways demonstrate deep devotion to a transcendent deity. This suggests that there is something in human beings that finds it meaningful and helpful to experience God as a being of ultimate authority. It suggests that life may be elevated by looking to and relying on a being of surpassing might, power, and glory, even if that means that one's life and one's choice are not entirely one's own.

Many in the West are becoming increasingly uncomfortable with-and suspicious of - authority, hierarchy, and institutions of all kinds. Even so, are there potential or even reported benefits that people perceive in experienceing a God who expects (or even commands) obedience, sacrifice, and commitment? Is there a place for Divine Authority in a contemporary culture of equality, social leveling, and other attempts to jettison many hierarchies?

When discussing parent-child relationships, Baumrind (1975) posited that simultaneously high levels of warmth and control are preferable. In the present study, we ask: Is it the same with experiences of God? Is perceiving and/or experiencing a high level of emotional closeness paired with a high level of authority in experiences of God beneficial in family relationships?

\section{Outcomes of Experiences of God}

Experiences of God as an authority figure or as a close confidant may be associated with varying aspects of family life. For example, Hertel and Donahue (1995) found that parents' images of God were associated with parenting styles and that there was a gender role effect on youths' images of God as love or as authority. Youths' images of God as love were more impacted by mothers' images of God as love and youths' images of God as authority were more impacted by fathers' images of God as authority. Shichida et al. (2015) qualitatively explored how viewing God as an authority figure reportedly impacted marriage relationships. They found that participants described characteristics of both vertical (God as authority figure) and horizontal (God as close confidant) relationships with God throughout participants' interviews, and that these images of God were associated with specific approaches to marriage, including how they ought to treat their spouse. Goodman and Dollahite (2006) have similarly suggested that scholars need to explore ways that couples and families involve God in their relationships.

\section{Gender Differences}

Scholars have suggested that there are gender differences in religiosity, with women significantly more religious (DeBono and Kuschpel 2014; Kim-Spoon et al. 2012). Nguyen and Zuckerman (2016) discussed the relationship between gender differences in religiosity and the possibility of gender specific images of God. They found that women tended to view God as a creator, as relational, and as a provider, while men tended to view God more as a provider and creator than as a ruler, but that gender differences were more noticeable when discussing God as a provider or creator, than when discussing God as a ruler. 


\section{Current Study}

This study explores how different types of transcendence-different experiences of God-may relate to marriage and family life. The specific research questions guiding this inquiry include: How do religious family members experience God? Is experiencing a high level of emotional closeness paired with a high level of authority in experiences of God meaningfully associated with marital and parentchild relationships? Do women and men experience God differently? We hope this in-depth look at experiences of God as an authority figure and/or a close confidant will shed light on the nexus of faith and family life.

\section{Conceptualization: Types of Transcendence}

Various religions view God differently, and there are also differences within faiths regarding how congregants personally perceive and experience God. Further, the same person may have perceptions of and experiences with different kinds of transcendence that may vary across time - and that may be in tension. Perceived relationships with God can be complex and varied in nature and type. One expression is an authority-based "vertical" experience of God that we will refer to as Directive Transcendence. Another is a more relational or "horizontal" experience of God that we refer to as Intimate Transcendence. One can also have a sense of experience of God that integrates or harmonizes both vertical (directive) and horizontal (intimate) elements that we refer to as Authoritative Transcendence.

By Directive Transcendence, we mean experiences of God mostly as an authority figure - a source of absolute Truth, a King, a Judge, a Ruler, a Lawgiver, or Lord to whom one is directly accountable for one's actions and from whom one can expect punishment when one sins or disobeys given commandments (Dollahite et al. in press).

By Intimate Transcendence we mean experiences of God primarily as a close confidant-a Healer, a Companion, a Guide, a Comforter, a Friend, or someone with whom one can have a close personal relationship (Dollahite et al. in press).

It has been argued that horizontal and vertical experiences of God are not mutually exclusive, but can, and perhaps should, co-exist to allow for a more complete religious experience (Goodenough 2001). Again, by Authoritative Transcendence we mean experiences of God as both an authority figure and as a close confidant—as both a source of absolute Truth (i.e., a King, a Judge, a Ruler, a Lawgiver), and as a Healer, a Companion, a Guide, a Comforter, or a Friend. Authoritative transcendence combines the ideas of the authority of a ruler with the responsiveness of a friend. Authoritative Transcendence may function differently than the simple addition of Intimate and Directive Transcendence. Rather than intimate and directive transcendent experiences of God competing for primacy, Authoritative Transcendence occurs when participants integrate their dualistic views of God as an authority and a confidant in a way that potentially creates a more holistic experience of God. 


\section{Methods}

\section{Participants}

Interviews used in this study are taken from the American Families of Faith (AFF) project. Religious families were purposively sampled in a two-stage selection process (Denzin and Lincoln 1994). Families were recruited through the clergy of the religious congregation to which they belonged. Once identified by clergy members, families were approached and asked if they wanted to participate or not. More than $90 \%$ of the referred families consented to be interviewed. Among more difficult-to-access faiths (e.g., Islam, Orthodox Judaism), snowball or participant referral sampling was sometimes employed.

Our sample consists of "exemplars" (Damon and Colby 2013). Religious leaders were asked to recommend families in their congregations they considered as "strong in their faith" and "successful... in their family relationships" to be interviewed. Most families attended religious services at least weekly. They reportedly gave an average of $7 \%$ of their income to their religion and spent $11 \mathrm{~h}$ a week in religious activities (including personal and home-based worship).

A total of 198 families were qualitatively interviewed ( $N=476$ individuals). All families consisted of married or remarried parents who had at least one child, with the average being 3.3 children per couple. Parents had been married an average of 20 years and with mean ages in the mid- to late-40 s (Mothers $=45$ years; Fathers $=47$ years). Of the 198 families interviewed, children were included in 55 of the interviews. Of the 476 individuals, 84 were children (44 females and 40 males), with ages ranging from 6 to 25 (average age was 16).

Social research on religion has been criticized for repeatedly employing predominantly Caucasianerican Christian samples (Alghafli et al. 2014; Mahoney 2010; Marks and Dollahite 2017). We strived to address and overcome both of these limitations with intentional sampling (e.g., Daly 2008). Ethnic and racial minority families and new immigrants were oversampled such that they comprise over half $(51 \%)$ of the total sample. Minority families were oversampled because they are both understudied and are generally more religious (Ghorpade et al. 2006; Perry 2016). Some of the ethnic and racial minorities in the sample include, but are not limited to, African American (17\%), Asian American (13\%), East Asian/East Indian (3\%), Latino (7\%), Middle Eastern (9\%), Native American (6\%), and Pacific Islander families (1\%). The European American (Caucasian) families included those from various European backgrounds. Of the 198 families interviewed, the religiousethnic make-up of the sample included: African American Christian (13\%), Asian Christian (12\%); Catholic and Orthodox (mixed ethnicities, 11\%), Evangelical Christian (mixed ethnicities, 12\%), Mainline Christian (mixed ethnicities, 10\%), Latter-day Saint (mixed ethnicities, 14\%), Jewish (mixed ethnicities, 16\%), and Muslim (mixed ethnicities, 12\%). Narratives reported verbatim in this paper for each religious-ethnic community as identified in the AFF project (americanfamiliesoffaith.byu.edu) are as follows: Asian Christian (3); Black Christian (3); Catholic and Orthodox Christian (mixed ethnicities, 5); Evangelical Christian 
(Caucasian, 10); Mainline Christian (Caucasian, 1); Latter-day Saint Christian (mixed ethnicities, 4); Jewish (Caucasian, 2); Muslim (mixed ethnicities, 3). (Total: 55\% Caucasian; 45\% Ethnic/Racial Minority).

Families who participated in this study were from 17 states, representing all 8 socio-religious regions of the nation identified by Silk and Walsh (2006), including the Mid Atlantic (6\%; DE, MD, PA), Midwest (2.5\%; OH, WI), Mountain West (3\%; ID, UT), New England (16\%; MA, CT), Northwest (12.5\%; OR, WA), Pacific (12.5\%; CA), the South/Gulf Coast (39.5\%; FL, GA, LA), and Southern Crossroads regions $(7.5 \%$; KS, OK). Wide ranges of socioeconomic and education levels were represented by participants, as indicated by housing situation and educational experience that ranged from GED to $\mathrm{PhD} / \mathrm{MD}$.

Thus, the sample is characterized by: (a) a high level of religious commitment, (b) rich racial and ethnic diversity, (c) religious diversity, (d) geographic and regional diversity, and (e) socioeconomic diversity.

\section{Interviewing}

Qualitative interviews were semi-structured and averaged about $2 \mathrm{~h}$ in length. Questions were open-ended and asked about participants' religion and family life (e.g., "How has your relationship with God influenced your relationship with each other?", "What are some of your deepest spiritual beliefs relating to marriage/family?", "How central is your religion to how you are as parents and children in this family?", "Can you think of a time when you believe God directly influenced your family in some way?", and "What do you believe are God's purposes for marriage and family?"). Follow-up questions were asked for clarification purposes.

Married couples were interviewed together first (husband and wife without children present) and then, in the 55 families where children were interviewed, the children joined the parents for the remaining questions. Many scholars argue that it is better to interview spouses separately to provide an environment that encourages honesty and is sensitive to gender and power issues (Seymour et al. 1995). Other scholars argue that interviewing couples or family members together allows topics to emerge and develop more fully as participants fill in each other's gaps and memory lapses, and in ways unanticipated by interviewers (Babbie 2004; Seymour et al. 1995). We decided that interviewing couples together would allow them to complement each other's thoughts and would respect the diverse cultural and religious beliefs and practices regarding opposite gendered individuals being alone (e.g., Muslim, Mormon, and Orthodox Jewish couples). Interviewers encouraged each member of the family to respond to each question s/he was present for to make sure each member was given equal opportunities to provide input. Interviews were transcribed verbatim and coded as explained next. 


\section{Measures and Coding Process}

\section{Team-Based Coding: Primary analysis}

A team-based qualitative approach was used for data analysis and coding (Marks 2015). A detailed codebook was developed and used to allow for a rigorous and thorough analysis of the more than 4200 single-spaced pages of data in the AFF project. Coders read through transcribed interviews systematically searching for accounts of how participants viewed and experienced God. The definition of viewing God as an authority figure (Directive Transcendence) included seeing God as an authoritative lawgiver, a king, a judge, a ruler; feeling a sense of fear of disobedience; seeing rules as coming from God; and feelings that one is to obey instead of asking God for something. The definition of viewing God as a close confidant (Intimate Transcendence) included viewing God as a close friend, a comforter, a guide, a healer; a sense of having a deep personal relationship with God; and being able to converse with God and thank God for things. The concepts of viewing God as a close confidant and/or as an authority figure were part of a larger coding project identifying dualities at the nexus of faith and family life (Dollahite et al. in press).

Interviews were divided among the seven coders such that each interview was only assigned to one coder who was asked to independently code for these two types of relationships with God. The coders were then asked to review each other's work and make note of accounts with which they disagreed. The disagreements were compiled and the original coder and the reviewing coder came together and decided if the account should be kept or not. Following this "check-and-balance" stage, the inter-rater reliability for this process was high $(\alpha>.90)$.

\section{Coding with NVivo}

Accounts of God as both an authority figure and as a close confidant in the same sentence or close set of sentences (Authoritative Transcendence) were identified through analysis in NVivo 11, after initial coding had been finished. Frequencies for each of these views-(a) separate and (b) combined-are reported in the findings and in Table 1.

\section{Team-Based Coding: Secondary Analysis}

A group of six undergraduate students (paid research assistants and students enrolled in a semester-long, upper-division research practicum course) comprised the team that read through the previously identified examples of experiences with God to determine what subthemes would also apply. Subthemes included emergent themes that the first author had identified through analyzing core themes that she had found to be: (1) clear (Can the view the account represents be easily determined?), (2) concise (Does the account avoid being wordy or labored?), and (3) compelling (Does the account resonate?). Coders were provided with a codebook that included explanations and examples of the possible subthemes, previously 
Table 1 Frequencies of themes identified

\begin{tabular}{|c|c|c|c|c|c|}
\hline Concept & $\begin{array}{l}\text { Number of } \\
\text { families (\%) }\end{array}$ & $\begin{array}{l}\text { Number of } \\
\text { examples } \\
(\%)\end{array}$ & Male & Female & $\begin{array}{l}\text { Male } \\
\text { and } \\
\text { Female }\end{array}$ \\
\hline $\begin{array}{l}\text { Theme 1: Intimate Transcendence (God as } \\
\text { close confidant) }\end{array}$ & $173(87.4)$ & 1194 & 551 & 607 & 34 \\
\hline $\begin{array}{l}\text { (A) God is personally interested and } \\
\text { blesses my family }\end{array}$ & $160(63.6)$ & 637 & 291 & 325 & 21 \\
\hline $\begin{array}{l}\text { (B) God is available at any time to help my } \\
\text { family }\end{array}$ & $130(65.7)$ & 407 & 157 & 238 & 12 \\
\hline $\begin{array}{l}\text { (C) I can trust God for help with family } \\
\text { relationships }\end{array}$ & $126(63.6)$ & 359 & 154 & 192 & 13 \\
\hline $\begin{array}{l}\text { (D) God heals and provides support for my } \\
\text { family }\end{array}$ & $125(63.1)$ & 284 & 101 & 172 & 11 \\
\hline $\begin{array}{l}\text { Theme 2: Directive Transcendence (God as } \\
\text { authority figure) }\end{array}$ & $169(85.4)$ & 1172 & 593 & 560 & 14 \\
\hline $\begin{array}{l}\text { (A) I submit my will to God to benefit my } \\
\text { family }\end{array}$ & $138(68.7)$ & 628 & 319 & 295 & 13 \\
\hline (B) God has a plan for my family & $132(66.7)$ & 397 & 196 & 199 & 2 \\
\hline $\begin{array}{l}\text { (C) God gives commandments that help } \\
\text { my family }\end{array}$ & $118(59.6)$ & 389 & 201 & 178 & 10 \\
\hline $\begin{array}{l}\text { Theme 3: Authoritative Transcendence } \\
\text { (God as authority figure and close } \\
\text { confidant) }\end{array}$ & $78(39.4)$ & 202 & 103 & 95 & 4 \\
\hline (A) God as guide in my family life & $44(22.2)$ & 84 & 42 & 41 & 1 \\
\hline $\begin{array}{l}\text { (B) I can trust God to help my } \\
\text { relationships }\end{array}$ & $44(22.2)$ & 75 & 41 & 34 & 0 \\
\hline $\begin{array}{l}\text { (C) I can converse with God about family } \\
\text { members }\end{array}$ & $22(11.1)$ & 33 & 17 & 15 & 1 \\
\hline
\end{tabular}

identified by the first author. The codebook is available at (americanfamiliesoffaith.byu.edu).

Students were put into groups such that each account identified in primary analyses was read and subthemes were coded by two students. These students reviewed each other's work and discussed any disagreements they had about what the other had coded and decided if the sub-theme should stay or be deleted from the account. Inter-rater reliability before disagreements was moderate $(\alpha=.66)$. After disagreements were resolved, inter-rater reliability was high $(\alpha>.90)$.

Analyses were conducted without dividing participants by religious affiliation because, for the purposes of this study, the authors were more interested in commonalities across religious groups rather than potential differences between them. 


\section{Findings}

Core themes within the accounts in each type of experience are presented and discussed. Some of the excerpts may conceivably relate to several identified themes, but are discussed as examples of the theme they best represent. The themes listed for each type of experience of God are listed from highest to lowest frequency. Table 1 provides the precise number of coded accounts for each of the discussed themes. Core themes include (1) Intimate Transcendence (God as a close confidant), (2) Directive Transcendence (God as an authority figure), and (3) Authoritative Transcendence (God as both an authority figure and a close confidant simultaneously). Sub-themes will be discussed within each major theme. Discussions of each theme and subtheme will also include application to family life as explained by participants (for consistency, we use the term "God" while, in quoted excerpts, retaining participants' use of more specific names of God such as Hashem, Allah, Jehovah, Jesus, Lord).

\section{Theme 1: Intimate Transcendence (God as a Close Confidant)}

In our primary analyses, 1194 accounts of Intimate Transcendence (God as a close confidant) were identified among $88 \%$ of families interviewed (an average of about seven accounts per interview). Secondary analyses identified subthemes including: (1) God is personally interested in and blesses my family, (2) God is available at any time to help my family, (3) I can trust God for help with family relationships, and (4) God heals and provides support for my family. Each of these categories are illustrated with accounts from participants.

\section{God is Personally Interested in and Blesses My Family}

Some participants seemed to feel that God cared about what happened in their family lives and believed that God was invested in helping them. When Tucker, ${ }^{2}$ a Caucasian Latter-day Saint Christian husband and father, was asked if religious beliefs or practices helped him avoid or lessen marital conflict, he explained:

We believe that our Heavenly Father is willing, able, and desires to help us in every decision we have to make in life. Not just the big decisions.... We believe he [also] wants to help us to give us the guidance in... the little daily activities.... We believe you can receive [help]. So especially when it comes to the way in which we reach decisions where there might be a differing point of view on how to handle something, we believe that our Heavenly Father is more than happy to... put impressions in our heart [and] in our minds to give us direction.

Sally, a Caucasian Evangelical Christian wife and mother, reported that while God was interested in her, she admittedly was not always interested in God:

\footnotetext{
${ }^{2}$ All names are pseudonyms.
} 
I $\operatorname{tr}[$ ied] to not need God.... Even looking back, even knowing that He's with me, and He's in control, and He will never leave me or forsake me, I still [sometimes] choose to feel like I don't need [Him] there to help me and encourage me, but I do. I do need God, and I do need my spouse, and I do need my children, and my family.

Grace, a Caucasian Evangelical Christian wife and mother, similarly shared how she and her husband were able to resolve family problems with God's influence:

We can pray about things together and the Lord can help us work things out. Sometimes one person has to give in and accept the other person's point of view, it helps to be able to pray about things. [I think that] God, He's the best counselor you could ever have.

Sometimes participants asked God to be involved in their family relationships, and sometimes participants recognized God's involvement without having asked for God's help. Whether they asked for God's involvement or not, many participants seemed to acknowledge God's involvement and availability in the way that things worked in their family relationships.

\section{God is Available at Any Time to Help My Family}

Accounts about how God was available at any time included accounts where participants reportedly talked with God whenever they desired, as well as accounts of participants feeling like God was always blessing them and their families. When Angela, an Italian Catholic Christian wife and mother, was asked what role God played in her life as a parent, she responded:

[I am] consoled by knowing the presence of God, God's presence in my life. I'm not alone. I, as bad as I sometimes feel. I am as a mother, or as a wife, [I still] feel like, God's presence is constant and steady and God always loves me, and that's consoling for me.

Shawn, a Caucasian Evangelical Christian husband and father, shared how God being present and "central" in his life blessed his marriage:

[W] seek to live out our life with God as the center of our life. He's just the center of everything. So if there's going to be a real integrity within our self, or integration of our relationship with God... then... there's no aspect of life where He isn't central.

Antony, a Latino Catholic Christian husband and father, similarly shared his conviction:

God is there. As much as you get wrapped up in society and work and school and your friends, and this, and that... you know God is there. God is there. And if my family understands this, knows that God is there, and no matter what they do, God will still be there, that if they take one step towards Him, He'll take three steps towards you. You are never alone, and no matter what happens, if you have faith, it will work out for you. 
When participants talked about God "being there" for them at all times, they often shared the personal importance this had for them and their ability to perform familial duties. Others, like Antony, wanted to make sure that their family members understood that God would always be available and willing to lend support or a helping hand when needed or desired. Many seemed to trust that God would help them in their family relationships, as discussed next.

\section{Can Trust God for Help with Family Relationships}

Trusting God seemed to be an important part of experiences of God as a close confidant. Many participants talked about being able to trust that God would always be there, that God was a safe person (safe haven/secure base) to whom problems or trials could be taken. Participants seemed to have an interpersonal trust with God. Some accounts related to trusting God overlapped with participants' reports that God was available at any time (to talk to, to turn to in hard times, etc.). However, these ideas are distinct because participants expressed that God was "available," no matter if they were able to trust God or not. In answer to a question asking if religion provided families with anything that the secular society did not provide, Andy, a Caucasian Evangelical Christian husband and father, indicated:

You know that no matter what's going on around you, there is some constant that's there, and that's God. He's never changing and He's going to be there. And we can bring all of our problems and cares to Him. And there is that foundation that... it's unmovable.

Jocelyn, a Black Christian wife and mother, discussed how religion impacted stressful and challenging times in her life:

I go back to my Mom's death. I think that was the most difficult situation that I've ever, ever had to contend with. I think it made me realize, first of all, the power of God, because that was a situation that was very difficult for me and my family to get through and He has brought us through. We're still dealing with it and struggling with it, but I think knowing that I can lean and depend on God and go to Him in prayer has sustained me and my family, and I think it helps to bring my family closer together and bring some members of my family closer to Him.

Jocelyn was one of many participants who mentioned how her family benefited by trusting God on an interpersonal level. Placing trust in God was also seen to affect more than relationships in family life. Emily, a Caucasian Evangelical Christian wife and mother, shared how she could trust God to intervene in the lives of her children when she was at a loss for what to do:

Many times you just have to pray.... For me it's a very personal thing. I can go to God and say: "I'm really concerned about this situation that this child is dealing with-help them." I can intervene on their behalf before God that He would work in the situation in their lives and help them. 
Participants' reports of trusting God varied. Many expressed a trust in God as one would trust a close friend. Participants also expressed their ability to trust God to help them navigate their family relationships and sometimes to help support them and heal them, as discussed next.

\section{God Heals and Provides Support for My Family}

Several of the accounts of intimate transcendence (God as a close confidant) seemed to reveal an attitude or belief that God is a source to whom one can go to feel healing of one's soul or support when faced with a tough situation. There were some parents who talked about passing on the importance of relying on God for support to their children. Lamiah, an East Indian Muslim mother, reflected that:

In the course of... trying to raise children... your faith has to be a significant factor in that.... To fulfill your responsibility, to pass along faith in God, and in understanding that God loves you, and keeps you. [You teach your children that God] takes care of you, and provides for you, and is there when even I am not there, and [that He] will sustain you and make you whole. You have to have faith... yourself, and then you have to instill that faith into your children.

Not only was finding support in God important to Lamiah, but she apparently felt a sense of urgency to pass along this knowledge and faith in God to her children.

Participants shared experiences where God provided perceived healing or support to their families during both mundane (i.e., daily challenges) and profound (e.g., death of a close family member) challenges. Raven, a Black Christian wife and mother, shared how she went to God before going to her husband when problems arose:

There are many times when things came up when we had issues and we had problems to deal with in our marriage-finances, relatives, or whatever. When problems came up, many times I would take it to God first and I'd pray about it first before I would even bring it to my husband because it helped me to get a perspective on it first (and a right perspective) because sometimes I was ready to go off the deep end.

Several participants shared accounts of support from God. Noor, an Asian Muslim wife and mother, was among those who shared how God had provided support for her family:

I think many times when one of my children was very ill, I did personal supplication to Allah and... He... calmed me down and helped me through the situation. I believe that God really has helped me personally; and... that God has also helped the whole family.

The concepts discussed with Theme 1 (God being personally interested in and blessing participants' families, God always being available to help families, trusting God with family relationships, God healing or providing support for families) relate to intimate transcendence. Families who were interviewed seemed to emphasize that God was intimately trusted. They trusted that God cared deeply about what 
happened to them and their families, and would provide healing and support when their family needed it. Although many participants emphasized experiences categorized as examples of intimate transcendence, many also expressed experiences of God as an authority figure, as discussed next.

\section{Theme 2: Directive Transcendence (God as an Authority Figure)}

In our primary analyses, 1172 accounts of God as an authority figure were identified among $86 \%$ of families interviewed-an average of about seven accounts per interview. Secondary analyses identified three sub-themes including: (1) I submit my will to God to benefit my family, (2) God has a plan for my family, and (3) God gives commandments that help my family. Each of these categories are discussed and illustrated next.

\section{Submit My will to God to Help My Family}

Analyses indicated that those who seemed to experience God as an authority figure felt they needed to submit their will to God. Choosing to give up what one wanted in order to do what God wanted was, reportedly, not always an easy task. In response to a question about how her relationship with God influenced her marriage, Xue, an Asian Christian wife and mother, expressed: "Although there are things that you disagree [with] or are difficult for you to obey reasonably, we should do them according to God's words."

When discussing the influence of religion on parental roles within marriage, the idea of "submission" to God surfaced several times. In response to the question about how his relationship with God influenced his relationship with his wife, Jimmy, a Caucasian Evangelical Christian husband and father, shared: "The more I submit to God, the better husband I become." There seemed to be something about one submitting one's will to God that impacted spousal humility and marital quality positively. Submitting one's will to God was not only seen in participants' accounts about marriage, but was also seen in comments about parenting. Evan, a Caucasian Latter-day Saint Christian husband and father, shared how "sacred" parenthood was for him:

Our church teaches that a role of a parent is very sacred. It's not something that you just happen upon, or [that] just happens. It happens for a reason and it's a sacred responsibility rather than just something that you have to deal with. In other words, there's a purpose behind it, and you really need to accept it as a responsibility from God.... [Y]ou've been given the sacred trust to help one of His children learn and grow in this capacity on earth.... it's a big responsibility. And we look at that as God given.

Like Xue, Jimmy, and Evan, many participants seemed to believe God has a "will” that involved profound, even "sacred," familial responsibilities. Many also discussed variations of what was frequently referenced as a divine "plan," as discussed next. 


\section{God has a Plan for My Family}

When participants talked about how they experienced God, many alluded to the idea that God had "a plan" for them-a plan that they were supposed to follow. It seemed that believing that God had a plan helped some participants to find purpose amidst hard moments in life. They were reportedly able to face challenges with a hope that otherwise may not have been possible. Indeed, some participants expressed a need to "trust" God's plan, even when they did not understand the plan. When asked if and how his religion was a strength to his marriage and family during challenging times, Ty, an African American Catholic Christian husband and father, shared that when one comes across something as potentially devastating as a severe health issue, one cannot only trust other humans (e.g., doctors), one must trust "the Lord":

Especially the health issues... that's not something you can just personally put your hands on and take care of... you trust doctors and stuff like that, but... it's all in the hands of the Lord.... [T] he Lord decides that situation... whatever happens, whatever tragedy... something good is gonna come out of it.... And you have to believe that.

Occasionally participants mentioned experiences where they had not originally recognized life experiences as part of God's plan for them but saw a "plan" in hindsight. Hannah, a Caucasian Jewish wife and mother, shared how a challenge with her husband seemed to be part of "Hashem's plan" even though it had occurred during a painful time. She queried:

But wasn't this actually, without our knowing it, all part of Hashem's plan?... We didn't like it. We suffered, because we were unhappy, because we weren't on the same path, right? But obviously this was how it was intended to work itself out, so that instead of you and me going divergent roads over it, we had to work together and find a place where we could be comfortable with each other and build a Jewish home together.

Many participants, like Hannah, seemed to engage in a kind of sacred revisionist history that focused on the good and the blessings that came as they endured pain, struggles, and heartache. As a result, God's plan was often clearer in retrospect than in the present. For several participants, God's plan often included expectations, or commandments, as discussed next.

\section{God Gives Commandments to Help My Family}

Many of the coded accounts identifying experiences of God as an authority figure included participants discussing how God had given rules or commandments that participants were required to implement and abide by within their families. Calvin, a Black Christian husband, said, "Marriage, for me, is a commandment of God." Thomas, a Caucasian Mainline Christian husband and father, felt that his wife and children were sent to him from God, and that God had commanded him to take care of these specific people. He explained: 
I believe this. I think Tasha does too, that God, before we were born, had already chosen... the mate that He was going to give us. I believe, we believe, in predestination. He's already predetermined what's going to happen in our life. So He has made Tasha to be my wife and me to be her husband. And to me that's a sacred thing. He set us apart to raise the children that he's given us to His glory. That's just a special thing.

When asked what the most important thing for him to do as a Caucasian Orthodox Jewish father was, David said:

Every parent wants, and especially in our circle, they want their children to grow up [in] what we call the right way, meaning that they are G-d fearing, they want to learn the scripture or they want to follow the divine commandments, and basically live a life full of the divine commandments.

In response to a question about what faith belief or practice he thought would be most vital in helping an outsider understand the importance of faith in his family life, Jake, a Caucasian Evangelical Christian husband and father, shared, "Obeying his [God's] laws, or his commands, or his teachings, is very important to have a successful life and a family." It appeared that many participants viewed following God's commandments as an important way to bless their families.

Yang, an Asian Christian wife and mother, shared why God's word from the Bible was so special for her family:

The Bible says: "Unless the Lord builds the house, its builders labor in vain." God gives our family blessings. We have [a] healthy family life if we do... according to the Bible.

Many participants seemed to gain a sense of purpose and direction from viewing God as someone who gave commandments they were to follow. Even so, several participants mentioned that they did not always agree with the commandments given.

Sometimes God-given family responsibilities were discussed or mentioned when a participant talked about believing in and following God's plan for oneself. In connection with feeling like God gave responsibilities, participants occasionally talked about their belief that they would one day be accountable to God for how they had fulfilled the responsibilities that He had given them as part of His plan for them. These ideas (submitting one's will to God to help one's family, God having a plan for families, and God giving commandments to help families) illustrate the concept of directive transcendence. Families who were interviewed seemed to have emphasized that God had a plan, a direction for their lives, and would reveal this direction through commandments. Further, many felt they would benefit by obediently following these directions, even when they did not align with personal desires. Participants did not solely report directive transcendent relationships with God. They also reported experiences of God as both a close confidant and an authority figure simultaneously (consistent with the concept of authoritative transcendence), as discussed next. 


\section{Theme 3: Authoritative Transcendence (God as Authority Figure and Close Confidant)}

Analyses identified 202 accounts where participants referenced God as both an authority figure and as a close confidant within the same set of sentences. We posit that when this occurs participants are having a different experience of God than when they express experiences of God as an authority figure and as a close confidant at different points during the interview. When these experiences happen in conjunction with each other, the participant may experience a more holistic view of God because of the types of combinations they are making between different perceptions of God. These "simultaneous" accounts spanned nearly 40\% of families. Although the number of accounts was relatively small comparatively, three sub-themes were identified upon further analysis including: (1) God as a guide in my family life, (2) I can trust God to help my relationships, and (3) I can converse with God about family matters. Discussion of accounts of each sub-theme follows.

\section{God as a Guide in My Family Life}

Another theme that was prevalent in the accounts of God as both an authority figure and a close confidant was that participants experienced God as a guide. Specifically, God was experienced as a guide who had knowledge about where participants and their families needed to be or what they needed to be doing in their lives. Accordingly, God was someone willing to give direction, guidance, or correction to help them reach the destination that God had in mind for them. Among these accounts, several participants expressed that they had specifically asked for guidance from God. Yuusif, an Arab Muslim husband and father, shared how he used prayer to petition God for guidance about matters important to his family:

When you hear bad news, there is prayer for it. When something good has happened, there is a prayer of thanks. Again, like I said: decisions. Should I take this charge, should I not? Should I move here, should I not? Should I do this? So there are [many ways of] actual[ly] seeking guidance from God.

Like Lian (an Asian Christian wife) and Yuusif (an Arab Muslim husband), Mark, a Caucasian Evangelical Christian father, shared how he and his wife felt the need for God's guidance:

[Our daughter] Amber is a gift from God. Our children are gifts from God. And therefore, we're responsible for them and we allow Him to direct us how to rear our children.

Kari, a Caucasian Evangelical Christian wife and mother, similarly shared how she and her husband went to God for direction regarding their marriage and children:

He's [a God] who we can go to if we have any questions. We'll go to the scripture or praying and finding out what our marriage should be, what our lives should be. [God is] a guide definitely... [to] where you're going to live, how to bring your children up. [He] gives us direction; helps us have love, the 
kind of love He has. So, we can work out problems when [we] have them, and we can pray about them together. It's great to have one person to go to that will give us the same answers so that whatever your divisiveness might be, you'll come to the same conclusion.

As participants shared experiences of God as a guide, it seemed that many also felt that they could trust God to provide this guidance. The sub-theme of experiencing trust in God as both an authority figure and a close confidant is explained next.

\section{Can Trust God to Help My Relationships}

Accounts showing that participants trusted God were frequently seen in accounts of God as a close confidant. However, this theme also appeared when analyzing accounts categorized as the combination of God as both an authority figure and God as a close confidant. The nature of how participants trusted God differed slightly between accounts of God as a close confidant and accounts of God as both an authority figure and close confidant. Accounts of God as a close confidant focused on an interpersonal trust with God, while accounts about God as both a close confidant and authority figure seemed to focus more on a trust related to God's authority. Benton, an African American Latter-day Saint Christian husband and father, shared how he trusted God to provide what was needed to accomplish what God had asked of him:

I'm blessed with being able to supply enough for my family... but I think that [the] Lord gave me the talent that I have to be able to support my family with what I do in life, and then when He calls you to do something, like [volunteer] work that I do at the church, He'll provide whatever you need, regardless of what it is.

Benton seemed to view God both as someone who had the authority to ask him to do certain things, and as One who will graciously "provide whatever you need" to make those assignments or "callings" successful experiences. Benton's conceptualization of God seemed to capture elements of both directive transcendence and intimate transcendence.

Lian, an Asian Christian wife and mother, shared how she and her husband, Wang, trusted God to help them decide about a move they were considering making. She recalled:

Last year, we wanted to move again. When we prayed to God, we asked God's will, "If you want us [to] stay [here], please prepare a job for us." It was wonderful to find this job. So whenever we have something, we pray to God [and] ask for God's will.

Note that Lian's petition to God includes both seeking a directive (i.e., Where do you "want us to stay"?) and a more relational, intimate request (i.e., "Please prepare a job for us."). Other participants shared how they trusted that God was listening to (and would answer) their petitions in a type of conversation, as discussed next. 


\section{Can Converse with God About Family Matters}

Conversations with God seemed to occur often within the context of participants' prayer. Several participants addressed a supreme being with the expectation of being treated as a close confidant. When asked what role God played in her parenting, Tara, a Caucasian Latter-day Saint Christian wife and mother, spoke of a combination of asking for guidance and of conversing with God:

I think we're always asking for help and guidance in what we do with our kids and how we interact with them and what might be best for them. [It's] just sort of a constant conversation with God.

As mentioned previously, some participants conversed with God about whether or where to move. Others conversed with God about what God's will for them was as a parent or spouse. A few participants shared experiences where they had talked with God about whom they should marry. Juan, a Latino Catholic Christian husband, related a conversation he had with God, across time, where he went through several names, asking God if this was the girl he should marry. He received several "no" responses, but finally got a "yes" when he asked about his wife, Celina.

Samuel, a Caucasian Evangelical Christian husband, tried to make sense of seeing God as both a father figure and as someone "way beyond all that." $\mathrm{He}$ reflected:

I would consider God fatherly and parental. I definitely look at God in that way, [but also] understanding that God is... way beyond all that. But... since He has communicated to us in those relational terms... I trust that that's probably the best way to deal with Him, 'cause that's the way He's talked to us.

Although Samuel seems to view God as someone "way beyond," he also seems to choose to communicate with God in relational "fatherly," "parental" terms. Some participants, however, seemed to struggle with experiencing a harmony with experiencing God as both an authority figure and a close confidant. Although only 79 (40\% of) families had accounts of experiences of God as both an authority figure and close confidant in the same close set of sentences, 156 (79\% of) families had accounts of quotes for God as an authority figure and accounts for God as a close confidant at different points throughout the interview, conveying that a majority of the families interviewed apparently had dualistic conceptions of God or strived to combine these differing experiences of God into a more holistic view of authoritative transcendence.

\section{Gender Analysis}

Gender-based analyses on the complete list of accounts of experiences of God as an authority figure and God as a close confidant were run to determine if the percentages revealed gender effects (Table 1). Chi square analyses were used to determine if the number of times males and females discussed experiences of God were statistically significant different from each other. Analyses demonstrated that 
there were no significant differences in the number of times women versus men discussed experiences of God as a close confidant or as an authority figure $\left(\chi^{2}\right.$ $(1)=2.708, p=.0998 ; \chi^{2}(1)=.888, p=.3460$ respectively). However, statistical differences were found in the number of times women discussed God as God heals and provides support for my family, God is available at any time to help my family, and I can trust God for help with family relationships as compared to men $\left(\chi^{2} \quad(1)=17.949, \quad p<.0001 ; \chi^{2}(1)=16.203, p<.0001 ; \chi^{2}(1)=4.173\right.$, $p=.0411$ respectively). We address potential implications of these differences in the discussion section.

\section{Discussion}

In this section, we first summarize the major findings and then discuss the implications of our findings in relation to other scholarly research-and offer practical applications in two major areas of family relationships: marital relationships and parent-child relationships. We then mention limitations of the study and finish with some conclusions.

\section{Summary of Major Findings}

This study examined how experiences of God as an authority figure and/or a close confidant may be associated with varying aspects of family life. Experiences of God as a close confidant (Intimate Transcendence) appeared to help participants (a) trust that God was always someone to whom one could turn when family life became difficult, (b) trust that God would help guide one through the difficulties s/he had and would encounter in her/his family relationships, (c) trust that God would be able to heal hard feelings among family members, and to (d) trust that God would provide support during trials.

Experiences of God as an authority figure (Directive Transcendence) seemed to help participants (a) identify clear expectations their family lives were supposed to meet, (b) feel accountable for their behaviors towards family members, (c) foster relational humility and improved quality as one submitted her/his will to God, and (d) feel a sense of purpose and direction because God had a plan for them and their families. Experiences of God simultaneously as an authority and confidant (Authoritative Transcendence) appeared to help participants (a) receive specific reliable divine direction, guidance, and correction in family life, (b) trust in God's divine authority and loving power to guide their families in accomplishing what God required of them, and (c) engage with God as an authoritative, yet kind figure, in meaningful and responsible conversations about God's will for their families.

Accounts of Directive and Intimate Transcendence (authority figure and close confidant) were both individually present in 156 out of 198 (79\%) families interviewed. Conversely, only 42 families (21\%) discussed only one type of transcendent experience of God. These numbers suggest that a significant majority of participants may have experienced a tension between experiences of God at the nexus of faith and family life. Forty percent (two out of every five families 
interviewed), however, seemed to at least occasionally experience God as both authority and confidant simultaneously-a blend that we refer to as Authoritative Transcendence.

\section{Relational Processes}

Each way of experiencing God, influenced by one's attachment to God and one's perspective of God's authority, can color one's expectations of or experiences with family members. Because one's experience of God can be potent, it might influence other areas of life, including family relationships. The "spillover hypothesis" has been used to suggest that within families, qualities of one relationship can spill over or transfer to other relationships, for good or ill (Emery et al. 1984; Gallagher et al. 2015). It is possible that for religious families, the perceived qualities of experiences of God can also impact relationships between spouses, between a parent and a child, or between siblings (Shichida et al. 2015).

If parents view God mainly as an authority figure (Directive Transcendence), they could be more likely to be strict, focus excessively on rules, and tend to punish their children. If parents view God more as a close confidant (Intimate Transcendence), they may be more likely to focus on being loving, attentively listening, and becoming friends with their children. More studies are needed to examine the types of relationships that family members have with one another and how these relationships correlate with one's perceived experiences of God.

\section{Marital Relationships}

\section{Gender Differences}

Some studies suggest that men may tend to be more hierarchical and women to be more relational in cognition, conversation, and in the ways that they connect with others (Cooper and Lewis 1995). However, our findings suggest that, while there may be nuanced gender differences among the specific ways that people experience God as a close confidant, gender may not play as important a role in the ways that men and women experience God more broadly. If men are more likely to experience and emphasize God as an authority figure, this could have significance for how they interact with their own wives and children. The same goes for women, who seemed to experience and emphasize God more as a close confidant. Although these experiences of God are not mutually exclusive, they may impact marriage and family life differently. When only one approach is experienced and emphasized to an extreme degree, harm to family relationships may occur. Balancing these two different experiences of God may bring a balance to faith and family relationships so that the benefits of exercising authority and of extending confidence and friendship can be enriching and beneficial for family members. Further empirical research is needed to explore this finding. 


\section{Sanctification of Marriage}

Additionally, the way in which one experiences God can contribute to sanctification, or how "sacred" one views marriage and family relationships (Burr et al. 2012; Mahoney et al. 2003). Sanctification can help individuals feel that their marriage and family relationships are meaningful, which can allow them to feel more fulfilled by these relationships. Sanctification can also help relationships because spouses are more likely to put forth great efforts to protect family relationships. Conversely, sanctification could be harmful to marriage for some families, including those in distressed circumstances. The ways that an individual or family experiences God may influence the extent to which one sanctifies relationships or other phenomena in her/his family life, which could influence the amount of benefit, or harm, that sanctification could provide.

\section{Parent-Child Relationships}

Throughout the interviews, experiences were shared where parents trusted God and prayed for help in raising their children. Some asked God to intervene in their children's lives. Others asked God to help them to know what they could do for their children. Thus, many parents placed trust in God. It appeared that many parents not only felt responsible to be obedient to God's commandments themselves, but also to help their children learn to be obedient.

Elsewhere (Dollahite et al. in press), we have demonstrated that extremes in religiosity can have dramatically negative effects on family relationships. Is it possible that if one experiences God via Directive or Intimate Transcendence in an extreme way, family life may be negatively influenced? The religious behaviors and attitudes of parents may be associated with the way that parents treat their children, but may also be related to how children adjust and develop in religious and other domains (Kim-Spoon et al. 2012). Bornstein and colleagues (2017) demonstrated that the religiousness of parents was associated with positive and negative parenting practices, which then influenced child adjustment in positive and negative ways. Other empirical work has indicated that when there is low attachment between a parent and a child, a parent's personal religiousness is positively associated with an adolescent's internalizing symptoms; however, when there is healthy attachment between a parent and a child, a parent's personal religiousness does not influence the internalizing symptoms of their adolescent child (Kim-Spoon et al. 2012). When considered together, these studies seem to suggest that consideration of the parentchild relationship and experiences of attachment within a family unit are important concepts to include when studying the effects of religiousness in family systems.

It is possible that the type of transcendent experience of God that a parent experiences may impact the way that the parent relates to her/his child. If parents experience God mainly as a distant authority figure (Directive Transcendence), they could be more likely to try to implement that same type of relationship with their children. This could exacerbate distance between parent and child. It could also cause push-back from an adolescent if parental authority is used harshly or excessively. If parents experience God as a close confidant (Intimate 
Transcendence), they could try to become good friends with their children. This type of relationship, if carried to the level of indulgence, might make the enforcement of rules less effective or less consistent. Perhaps neither type of relationship is inherently bad or wrong, but when only one is implemented in an imbalanced way, it may be easier for relational harm to occur.

We suggest that when the two types of experiences of God are combined into an Authoritative Transcendent experience of God, parents may be better equipped to relate to and with their children. Parents may be better able to balance being an authority figure to, and a close confidant for their children, which could increase the likelihood of a healthy, high-attachment relationship.

\section{Limitations and Future Directions}

Given the nature of the sample and methods, this study is not generalizable to a broad population. Only moderately to highly religious marriage-based (Abrahamic faith) families were interviewed due to the aim of the AFF project to explore marital and parental relationships among religious families. However, it could be beneficial to interview religions that are not classified as Abrahamic to understand how their views of God influence their family lives. Families of other faiths may even have different ways of experiencing God than most of the participants in the AFF project. The way we coded Authoritative Transcendence (looking for examples of both vertical transcendence (authority) and horizontal transcendence (intimate) very near each other in the interview may not be an indication of a separate type of transcendence but, rather, merely reflect variations in personal expression. Further exploration of measurement is warranted. This study only captured the participants at one point in time and, given the dynamism in many Americans' religious and spiritual lives, it is likely that, if we had talked with them at other times in their lives, they may well have had other experiences of God.

\section{Conclusion}

In the words of Robert Ingersoll, "It is difficult for a child to find a father in God, unless the child first finds something of God in his father" (Marks and Dollahite 2017, p. 143). Indeed, there is empirical evidence that close parent-child relationships are a salient factor in successfully transmitting religiosity across generations (Kim-Spoon et al. 2012; Bengston et al. 2013). In the present study we see, however, that the type of God a parent "finds" and relates with may also influence their own attributes and aims as a parent and partner.

As we better understand how religious experience intersects with and influences family life, we can help families draw on their experience of God to benefit their family relationships. Through understanding how individuals may perceive and experience personal relationships with God, we can better understand influences on family relationships and what may or may not be helpful in building and strengthening family bonds. Participants experienced God in complex ways and better understanding of these experiences and conceptualizations may facilitate 
greater awareness of how religious people connect experiences with God to family relationships.

It appears that many Americans of faith continue to seek to experience an Authoritative God as well as a kind and loving God and that this has meaningful implications for how they relate to members of their families. Perhaps people want a secure attachment to a God with transcendent authority to direct and to respond, to lead and to comfort, and to guide and to love. In a world of rapidly evolving technologies, increasingly unstable economies, dramatically fluctuating weather, and dynamically changing cultures, many seem to believe that experiences of an authoritative God who can guide one's family through the dangers and changes of modern marriage and family life is worth the costs.

\section{References}

Alghafli, Z., T. Hatch, and L. Marks. 2014. Religion and relationships in Muslim families. Religions 5: 814-833.

Babbie, E. 2004. The practice of social research, 10th ed. Belmont, CA: Wadsworth.

Baumrind, D. 1975. The contributions of the family to the development of competence in children. Schizophrenia Bulletin 1(14): 12-37.

Bengston, V.L., N.M. Putney, and S. Harris. 2013. Families and faith. New York, NY: Oxford University Press.

Bornstein, M.H., D.L. Putnick, J.E. Lansford, S.M. Al-Hassan, and D. Baachini. 2017. 'Mixed blessings': Parental religiousness, parenting, and child adjustment in global perspective. Journal of Child Psychology and Psychiatry 58(8): 880-892.

Burr, W.R., L.D. Marks, and R.D. Day. 2012. Sacred matters: Religion and spirituality in families. New York: Routledge.

Cooper, C.L., and S. Lewis. 1995. Working together: Men and women in organizations. Leadership \& Organization Development Journal 16: 29-31.

Daly, K. 2008. Qualitative methods for family studies and human development. Thousand Oaks, CA: Sage.

Damon, W., and A. Colby. 2013. Why a true account of human development requires exemplar research. In Exemplar methods and research: Strategies for investigation. New directions for child and adolescent development, eds. Matsuba, M.K., P.E. King, and K.C. Bronk, 142, 13-25. San Francisco, CA: Wiley Periodicals, Inc.

DeBono, K.G., and A. Kuschpel. 2014. Gender differences in religiosity: The role of self-monitoring. North American Journal of Psychology 16(2): 415-425.

Denzin, N.K., and Y.S. Lincoln (eds.). 1994. Handbook of qualitative research. Thousand Oaks, CA: Sage.

Dollahite, D.C., L.D. Marks, and H. Dalton. in press. Why religion helps and harms families: A conceptual model of a system of dualities at the nexus of faith and family life. Journal of Family Theory \& Review.

Ellison, C.G., and J. Lee. 2010. Spiritual struggles and psychological distress: Is there a dark side of religion? Social Indicators Research 98(3): 501-517.

Emery, R.E., E.M. Hetherington, and L.F. Dilalla. 1984. Divorce, children, and social policy. In Child development research and social policy, ed. H.W. Stevenson and A.E. Seigel, 189-266. Chicago, IL: University of Chicago Press.

Exline, J.J. 2002. Stumbling blocks on the religious road: Fractured relationships, nagging vices, and the inner struggle to believe. Psychological Inquiry 13(3): 182-189.

Froese, P., and C. Bader. 2010. America's four Gods. New York, NY: Oxford University Press. 
Gall, T.L., V. Basque, M. Damasceno-Scott, and G. Vardy. 2007. Spirituality and the current adjustment of adult survivors of childhood sexual abuse. Journal for the Scientific Study of Religion 46(1): 101-117.

Gallagher, E., A. Huth-Bocks, and T. Schmitt. 2015. The impact of mothers' relationship quality and parenting on children's peer relationships. Journal of Family Issues 36: 421-442.

Ghorpade, J., J.R. Lackritz, and G. Singh. 2006. Intrinsic religious orientation among minorities in the United States. International Journal for the Psychology of Religion 16(1): 51-62.

Goodenough, U. 2001. Vertical and horizontal transcendence. Zygon 36: 21-31.

Goodman, M.A., and D.C. Dollahite. 2006. How religious couples perceive the influence of god in their marriage. Review of Religious Research 48: 141-155.

Granqvist, P. 1998. Religiousness and perceived childhood attachment. Journal for the Scientific Study of Religion 37(2): 350-367.

Granqvist, P., and L.A. Kirkpatrick. 2013. Religion, spirituality, and attachment. In APA handbook of psychology, religion, and spirituality: (vol 1). Context, theory, and research, ed. K.I. Pargament, 139-155. Washington, DC: APA.

Granqvist, P., M. Mikulincer, and P.R. Shaver. 2010. Religion as attachment: Normative processes and individual differences. Personality and Social Psychology Review 14: 49-59.

Hertel, B.R., and M.J. Donahue. 1995. Parental influences on God images among children. Journal for the Scientific Study of Religion 34(2): 186-199.

Kim-Spoon, J., G.S. Longo, and M.E. McCullough. 2012. Parent-adolescent relationships quality as a moderator for the influence of parents' religiousness on adolescents' religiousness and adjustment. Journal of Youth and Adolescence 41: 1576-1587.

Knabb, J.J., and M.Y. Emerson. 2013. "I will be your God and you will be my people": Attachment theory and the grand narrative of scripture. Pastoral Psychology 62: 827-841. https://doi.org/10. 1007/s11089-012-0500-x.

Konieczny, M.E. 2013. The spirit's tether. New York, NY: Oxford University Press.

Mahoney, A. 2010. Religion in families, 1999-2009: A relational spirituality framework. Journal of Marriage and Family 72: 805-827. https://doi.org/10.1111/j.1741-3737.2010.00732.x.

Mahoney, A. 2013. The spirituality of us: Relational spirituality in the context of family relationships. In APA handbook of psychology, religion, and spirituality, vol. I, ed. K.I. Pargament, J.J. Exline and J. Jones, 365-389. Washington, DC: APA.

Mahoney, A., K.I. Pargament, A. Murray-Swank, and N. Murray-Swank. 2003. Religion and the sanctification of family relationships. Review of Religious Research 44: 220-236.

Marks, L.D. 2015. A pragmatic, step-by-step guide for qualitative methods: Capturing the disaster and long-term recovery stories of Katrina and Rita. Current Psychology 34: 494-505.

Marks, L.D., and D.C. Dollahite. 2017. Religion and families. New York: Taylor \& Francis.

Miner, M., M. Dowson, and K. Malone. 2014. Attachment to God, psychological need satisfaction, and psychological well-being among Christians. Journal of Psychology \& Theology 42(4): 326-342.

Nguyen, T.T., and M. Zuckerman. 2016. The links of God images to women's religiosity and coping with depression: A socialization explanation of gender difference in religiosity. Psychology of Religion and Spirituality 8(4): 309-317.

Omer, H., S.G. Steinmetz, T. Carthy, and A. Von Schlippe. 2013. The anchoring function: Parental authority and the parent-child bond. Family Process 52: 193-206.

Pargament, K.I., and A. Mahoney. 2005. Sacred matters: Sanctification as a vital topic for the psychology of religion. The International Journal for the Psychology of Religion 15(3): 179-198.

Perry, S.L. 2016. Perceived spousal religiosity and marital quality across racial and ethnic groups. Family Relations 65(2): 327-341.

Selvam, S.G. 2014. Influence of family on how youth relate to God. In Youth and family in today's India, ed. S. Fernando and J. Pudumai Doss, 6-80. Chennai: Don Bosco.

Seymour, J., G. Dix, and T. Eardley. 1995. Joint accounts: Methodology and practice in research interviews with couples. New York: Social Policy Research Unity, University of York.

Shichida, T., D.C. Dollahite, and J.S. Carroll. 2015. How the perception of god as a transcendent moral authority influences marital connection among American Christians. Journal of Psychology and Christianity 34: 40-52.

Silk, M., and A. Walsh. 2006. Religion by region: Religion and public life in the United States. Blue Ridge Summit, PA: AltaMira. 